Tropical Journal of Pharmaceutical Research October 2014; 13 (10): 1659-1666

ISSN: $1596-5996$ (print); 1596-9827 (electronic)

(C) Pharmacotherapy Group, Faculty of Pharmacy, University of Benin, Benin City, 300001 Nigeria.

All rights reserved.

Available online at http://www.tjpr.org

Original Research Article

http://dx.doi.org/10.4314/tjpr.v13i10.13

\title{
Antinociceptive Properties and Acute Toxicity of Ethanol Extract of Bromelia laciniosa Mart. ex Schult. f. (Bromeliaceae)
}

\author{
Sarah RG de Lima-Saraiva ${ }^{1}$, Henrique CC Saraiva ${ }^{2}$, Juliane C Silva ${ }^{2}$, Leonardo \\ F Neves ${ }^{2}$, Patrícia KF Damasceno ${ }^{3}$, Carla RC Branco ${ }^{3}$, Alexsandro Branco ${ }^{3}$, \\ Elba LC Amorim ${ }^{1}$ and Jackson RGS Almeida ${ }^{2}$ \\ ${ }^{1}$ Universidade Federal de Pernambuco, 50.740-521, Recife, Pernambuco, ${ }^{2}$ Universidade Federal do Vale do São Francisco, \\ 56.304-205, Petrolina, Pernambuco, ${ }^{3}$ Universidade Estadual de Feira de Santana, 44.036-900, Feira de Santana, Bahia, Brazil \\ *For correspondence: Email: jackson.guedes@univasf.edu.br; Tel/Fax: + 55-87-21016862
}

\begin{abstract}
Purpose: To investigate the antinociceptive activity and acute toxicity of the ethanol extract of Bromelia laciniosa leaf.

Methods: A high performance liquid chromatography HPLC fingerprint of phenolic compounds was developed. The antinociceptive effect of ethanol extract (Bl-EtOH) in mice was carried out using chemical (writhing and formalin) and thermal (hot plate) models of nociception. The acute toxicity of the extract was performed in mice using doses of $2.0 \mathrm{~g} / \mathrm{kg}$ intraperitoneally and $5.0 \mathrm{~g} / \mathrm{kg}$ orally. Blood was removed for laboratory analysis of hematological and biochemical parameters.

Results: $\mathrm{Bl}-\mathrm{EtOH}(100,200$ and $400 \mathrm{mg} / \mathrm{kg}$, i.p.) reduced the number of writhing $(91.80,93.44$ and $78.68 \%$, respectively) and the number of paw licks during the first (60.86, 62.84 and $66.79 \%$ ) and second phase (91.93, 82.18 and $88.73 \%$ ) of the formalin test. Naloxone $(1.5 \mathrm{mg} / \mathrm{kg}$, i.p.) antagonized the antinociceptive action of $\mathrm{Bl}-\mathrm{EtOH}(100 \mathrm{mg} / \mathrm{kg})$, and this finding suggests involvement of opioid mechanism. The effect of Bl-EtOH on hot plate response provides a confirmation of its central effect. Conclusion: B. laciniosa leaf extract has antinociceptive properties. Peripheral, and at least in part, central mechanisms, may be involved in this antinociceptive effect. The ethanol leaf extract apparently presents no significant toxicity.
\end{abstract}

Keywords: Bromelia laciniosa, Nociception, Pain, Writhing, Acute toxicity

Tropical Journal of Pharmaceutical Research is indexed by Science Citation Index (SciSearch), Scopus, International Pharmaceutical Abstract, Chemical Abstracts, Embase, Index Copernicus, EBSCO, African Index Medicus, JournalSeek, Journal Citation Reports/Science Edition, Directory of Open Access Journals (DOAJ), African Journal Online, Bioline International, Open-J-Gate and Pharmacy Abstracts

\section{INTRODUCTION}

The Bromeliaceae, one of the largest botanical families of the New World, is distributed extensively in tropical America [1]. This family comprises 58 genera and 3172 species [2]. Considering the large number of species of the Bromeliaceae family, few have been studied chemically so far. Despite this, there is a considerable amount of identified compounds, which mostly belong to the class of triterpenoids and flavonoids. Other classes of compounds such as sterols, diterpenes, cinnamic acids, lignans, nitrogen compounds, amongst others, were also identified [3]. Some studies have demonstrated that species of the Bromeliaceae family have pharmacological properties such as antioedematogenic and free radical scavenging [4], antinociceptive and anti-inflammatory [5], 
anti-allergic [6], antiulcer [7], cytotoxic [8], antioxidant and antimycobacterial activities [9].

Bromelia is one of the most diverse genera within Bromeliaceae and includes 56 species [2]. Some species of this genus are used in traditional medicine as a vermifuge, anti-helmintic, diuretic, in cases of respiratory and kidney problems, intestinal disorders, diabetes, amongst others [10]. Bromelia antiacantha is one of the most studied species [11]. Bromelia laciniosa is a species native to the Brazilian Caatinga which is known in the Northeast region of Brazil as "macambira" and is used in the alimentation of man and domestic animals, especially in times of drought [12]. From the base of the leaves is extracted a mass, that produces a type of bread [13]. The main therapeutic indications are for treating child colic, diarrhea, fever, jaundice, dandruff and hepatitis [14]. The decoction of the roots is also popularly used against hepatitis and intestinal disorders, as a diuretic, while the dried and powdered leaves are used in cooking as a source of protein $[3,10]$.

Considering the popular use and because of the scarcity of pharmacological studies about this species, this study evaluated the antinociceptive activity as well as the acute toxicity of the ethanolic extract from leaves of Bromelia laciniosa in mice.

\section{EXPERIMENTAL}

\section{Plant material}

The leaves of Bromelia laciniosa Mart. ex Schult. f. were collected in the city of Petrolina, State of Pernambuco, Brazil, in January of 2011 (Coordinates 08 $59^{\prime} 16.90^{\prime \prime} S$ and 40 35'20.60" W). A voucher specimen (no. 6442) was deposited at the Herbarium Vale do São Francisco (HVASF) of the Universidade Federal do Vale do São Francisco.

\section{Preparation of extracts}

The leaves of $B$. laciniosa dried and pulverized $(879 \mathrm{~g})$ were subjected to maceration with $95 \%$ EtOH for $72 \mathrm{~h}$. The solution was filtered and concentrated in a rotatory evaporator oven at 50 $\mathrm{oC}$, producing $39 \mathrm{~g}$ of crude ethanol extract (Bl$\mathrm{EtOH})$.

\section{Analysis of Bl-EtOH by high performance liquid chromatography (HPLC)}

The solvents used in high performance liquid chromatography are of analytical grade from Merck®. A Milli-Q System® (Bedford, MA, USA) was used to purify the water. Analysis using high performance liquid chromatography was performed on a Merck-Hitachi liquid chromatograph LaChrom Elite $®$ equipped with a VRW HITACHI L-2130 pump, a VRW HITACHI L-2300 Diode-Array Detector (DAD), and an auto sampler with a $100 \mu \mathrm{l}$ loop. The data was acquired and processed using Ezchrom Elite software. The extract was analyzed using a reverse-phase HPLC column: Purospher® STAR RP-18e (250 mm × $4.6 \mathrm{~mm}$ i.d., $5 \mu \mathrm{m})$ column (Merck). The mobile phase was composed of solvent (A) $\mathrm{H}_{2} \mathrm{O} / \mathrm{H}_{3} \mathrm{PO}_{4} \quad 0.1 \%$ and solvent $(B)$ $\mathrm{MeOH}$. The solvent gradient was composed of $\mathrm{A}$ $(75-0 \%)$ and B (25 - $100 \%)$ for $20 \mathrm{~min}$, then $100 \% \mathrm{~B}$ for $4 \mathrm{~min}$, then again at the initial conditions (75 \% A and $25 \% \mathrm{~B}$ ) for $10 \mathrm{~min}$. $A$ flow rate of $1.0 \mathrm{ml} / \mathrm{min}$ was used in a $30^{\circ} \mathrm{C}$ oven, and $20 \mu \mathrm{l}$ of each sample was injected. The procedure was repeated three times for each sample. Samples and mobile phases were filtered through a $0.22 \mu \mathrm{m}$ Millipore filter prior to HPLC injection. Spectra data were recorded from to 200 to $400 \mathrm{~nm}$ during the entire run.

\section{Animals}

Male and female adult albino Swiss mice (25 - 35 g) were used throughout this study. The animals were randomly housed in appropriate cages at $22 \pm 2{ }^{\circ} \mathrm{C}$ on a $12 \mathrm{~h} \mathrm{light/dark}$ cycle (lights on at 6:00 a.m.) with free access to food and water. When necessary, animals were deprived of food $12 \mathrm{~h}$ prior to the experiments. Experimental protocols and procedures were approved by the Federal University of Vale do São Francisco Animal Care and Use Committee by number 21051023.

\section{Acetic acid-induced writhing test in mice}

This test was performed as described by Koster et al [15]. Mice $(n=6)$ were intraperitoneally pretreated $30 \mathrm{~min}$ before the nociceptive agent, acetic acid $0.9 \%(\mathrm{v} / \mathrm{v}, 10 \mathrm{ml} / \mathrm{kg})$. Vehicle (saline), $\mathrm{Bl}-\mathrm{EtOH}$ (100, 200 and $400 \mathrm{mg} / \mathrm{kg}$, body weight), acetylsalicylic acid (ASA, $200 \mathrm{mg} / \mathrm{kg}$ ) and morphine $(10 \mathrm{mg} / \mathrm{kg}$ ) were administered before acetic acid injection. Following the injection of acetic acid, the intensity of nociceptive behavior was quantified by counting the total number of writhes (a response consisting of contraction of the abdominal wall, pelvic rotation followed by hind limb extension) occurring between 5 and 15 min after stimulus injection [16].

\section{Formalin test}

Twenty microlitres of $2.5 \%$ formalin was injected subcutaneously into the right hind paw of mice. 
The time (in seconds) spent in licking and biting responses of the injected paw was taken as an indicator of pain response. Responses were measured for 5 min after formalin injection (first phase, neurogenic phase) and $15-30$ min after formalin injection (second phase, inflammatory phase). BI-EtOH (100, 200 and $400 \mathrm{mg} / \mathrm{kg})$, ASA $(200 \mathrm{mg} / \mathrm{kg})$ and morphine $(10 \mathrm{mg} / \mathrm{kg})$ were administered intraperitoneally $60 \mathrm{~min}$ before formalin injection. Control animals received the same volume of saline. Mice were observed in the chambers with a mirror mounted on three sides to allow view of the paws [17].

\section{Hot plate test}

Mice were pre-selected on the hot plate at $55 \pm$ $0.5{ }^{\circ} \mathrm{C}$. Licks on the rear paws were the parameters of observation. Animals showing a reaction time (latency for licking the hind feet or jumping) greater than $20 \mathrm{~s}$ were discarded. The animals were then treated with vehicle (saline, $0.1 \mathrm{ml} / 10 \mathrm{~g})$, morphine $(10 \mathrm{mg} / \mathrm{kg})$ and BI-EtOH $(100,200$ and $400 \mathrm{mg} / \mathrm{kg}$ ) intraperitoneally. Latency time (in seconds) for each mouse was determined on the hot plate during the maximum period of $20 \mathrm{~s}$, at intervals of $30,60,90$ and 120 min after the administration of the extract [18].

\section{Acute toxicity}

Animals were randomly divided in groups of five male and five female Swiss mice $(n=10)$. Animals were administered $2.0 \mathrm{~g} / \mathrm{kg}$ intraperitoneally and $5.0 \mathrm{~g} / \mathrm{kg}$ orally of the crude ethanol extract of Bromelia laciniosa. Control group received vehicle. Subsequently, the animals were observed for 14 days to evaluate the presence of signs of toxicity. Mortality in each group within 72 $\mathrm{h}$ was recorded. $\mathrm{LD}_{50}$ was estimated by the method described by Litchfield \& Wilcoxon [19]. The mice were assessed daily throughout the study to monitor their body weight variation, consumption of food and water.

\section{Analysis of hematological and biochemical parameters}

For the evaluation of hematological and biochemical parameters of blood was evaluated using the method described by Vasconcelos et al [20]. Blood was removed after 14 days through brachial plexus for laboratory analysis of hematological parameters: count of erythrocytes, hemoglobin, hematocrit, the mean corpuscular volume (MCV), the mean corpuscular hemoglobin $(\mathrm{MCH})$, the mean corpuscular hemoglobin concentration (MCHC), leukocytes, lymphocytes and platelets. The biochemical parameters analyzed in serum samples were triglycerides, AST/TGO, ALT/TGP, urea and creatinine. For the determination of hematological parameters, hematology analyser Sysmex XT-2000 was used. For the determination of biochemical parameters, an automatic analyser Wiener BT 3000 Plus was used.

\section{Statistical analysis}

The data obtained were analyzed using the GraphPad Prism ${ }^{\circledR}$ version 4.0 and expressed as mean \pm SEM. Statistically significant differences between groups were calculated by the application of analysis of variance (ANOVA) followed by Dunnett's test. Values were considered statistically significant at $p<0.05$.

\section{RESULTS}

\section{Phytochemical profile of extract}

Phenolic profiles at $320 \mathrm{~nm}$ for the Bl-EtOH evaluated are presented in Figure 1. The chromatogram shows the presence of nine peaks with different retention times: 11.79 (1), 14.44 (2), 15.14 (3), 15.57 (4), 16.67 (5), 17.62 (6), 18.09 (7), 19.01 (8) and 19.89 (9). Based on their UV-Vis spectral data and their retention time, the compounds have UV band characteristic for coumarin and flavonoid derivatives. These compounds are under investigation.

\section{Anti-nociceptive activity of extract}

$\mathrm{BI}-\mathrm{EtOH}$ significantly reduced writhing induced by $0.9 \%$ acetic acid. The significant protective effects were observed as $91.80,93.44$ and 78.68 $\%(p<0.01)$ at 100,200 and $400 \mathrm{mg} / \mathrm{kg}$ of the extract, respectively, while ASA $(200 \mathrm{mg} / \mathrm{kg})$ had $95.08 \%$. Morphine $(10 \mathrm{mg} / \mathrm{kg})$ abolished the nociceptive response (Figure 2).

\section{Analgesic activity of extract}

$\mathrm{BI}$-EtOH had analgesic effects on both the first (0 - 5) and second phase (15 - 30) of formalininduced pain. These phases correspond to neurogenic and inflammatory pains, respectively. $\mathrm{BI}-\mathrm{EtOH} \quad(100,200$ and $400 \mathrm{mg} / \mathrm{kg}$, i.p.) decreased by $60.86,62.84$ and $66.79 \%$, respectively, the paw licking time in the first phase, as well as $91.93,82.18$ and $88.73 \%$, respectively, in the second phase of the formalin test (Figure 3). The treatment with acetylsalicylic acid and morphine was also able to inhibit the first and second phases. The pre-treatment with naloxone $(1.5 \mathrm{mg} / \mathrm{kg}$, i.p.) reversed the 


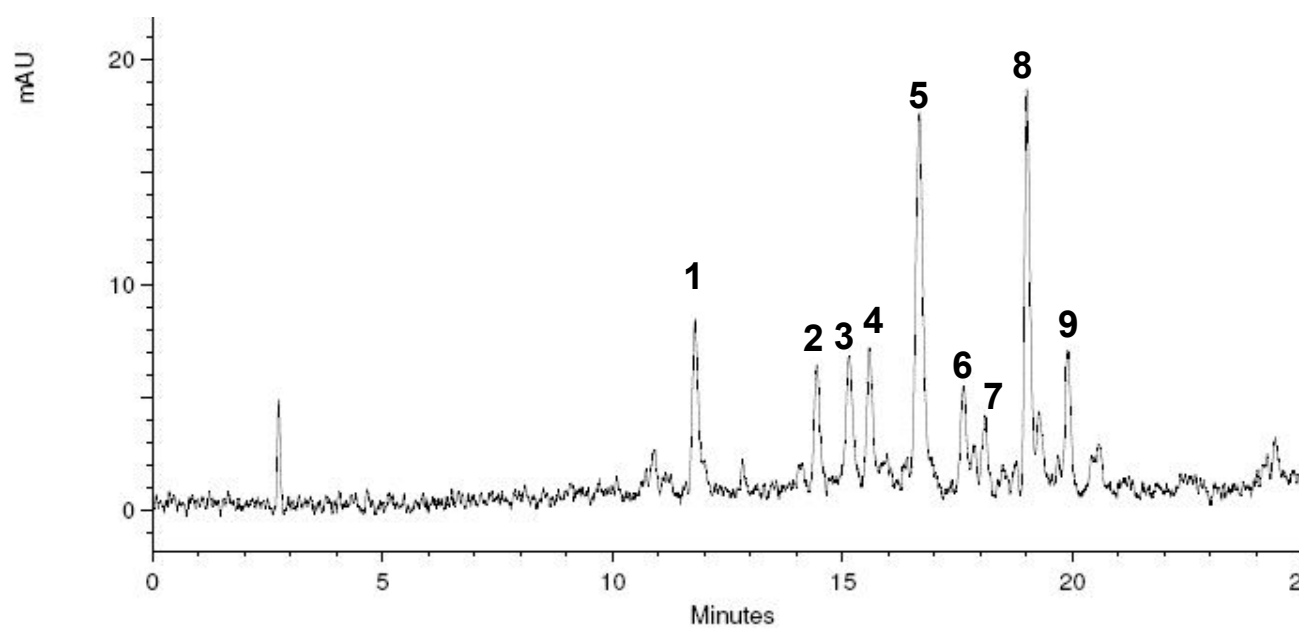

Figure 1: High performance liquid chromatography profile of Bromelia laciniosa ethanol extract recorded at 320 $\mathrm{nm}$

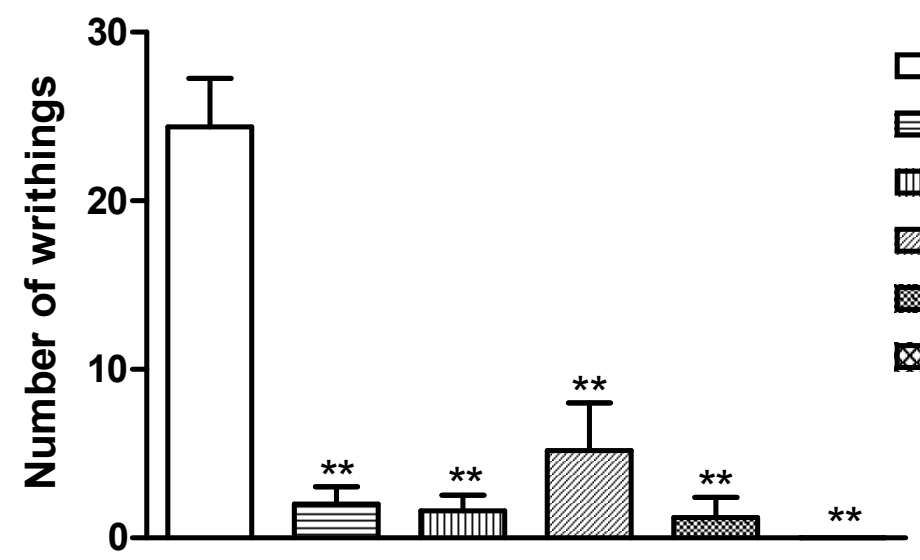

Figure 2: Antinociceptive activity of $B$. laciniosa (BI-EtOH 100, 200 and $400 \mathrm{mg} / \mathrm{kg}$ ), acetylsalicylic acid (ASA 200 $\mathrm{mg} / \mathrm{kg}$ ) and morphine $(10 \mathrm{mg} / \mathrm{kg})$ on acetic acid induced writhing testl values are mean \pm S.E.M. ${ }^{* *} p<0.01$, significantly different from control; ANOVA followed Dunnett's test $(n=6)$

(a) First phase

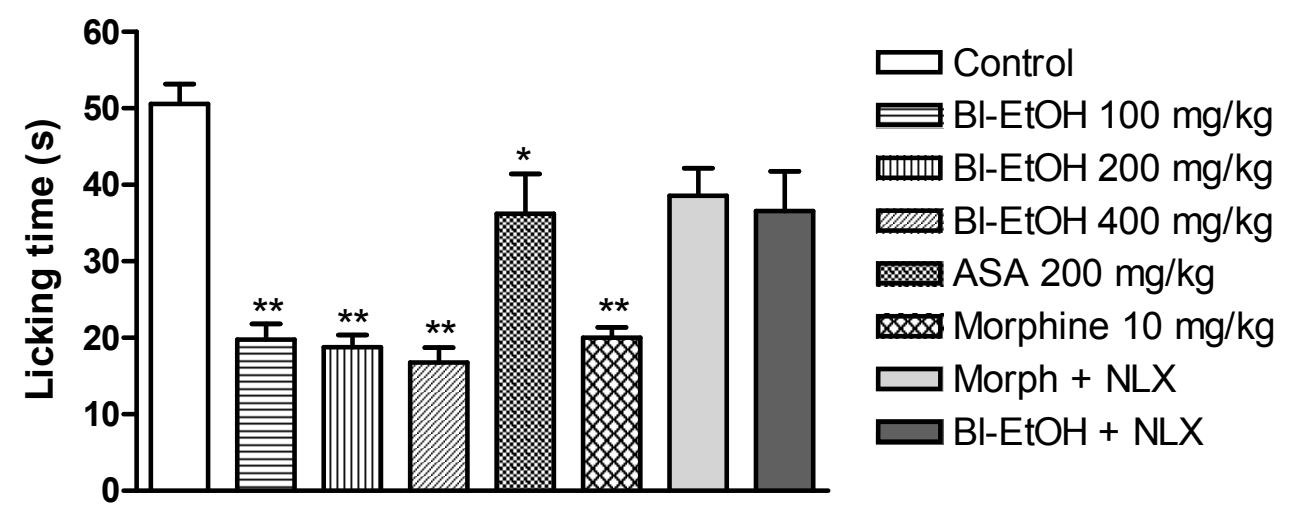


(b)

\section{Second phase}
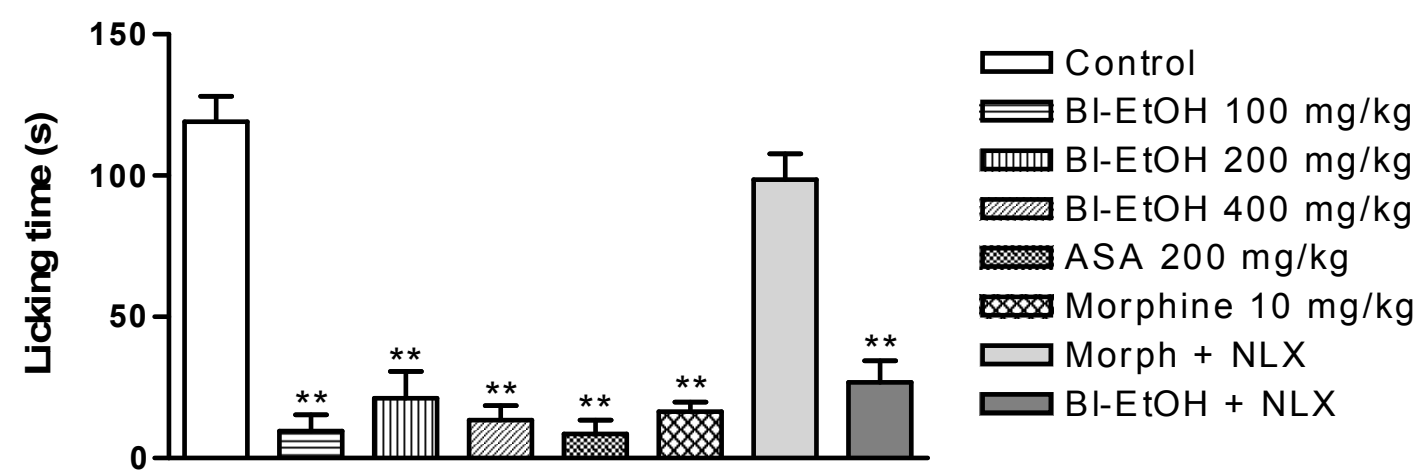

Figure 3: Effect of ethanol extract of $B$. laciniosa (BI-EtOH), acetylsalicylic acid (ASA), morphine, morphine + naloxone (Morph + NLX; $10 \mathrm{mg}+1.5 \mathrm{mg} / \mathrm{kg})$ and BI-EtOH + NLX (100 mg + $1.5 \mathrm{mg} / \mathrm{kg})$ on formalin test; values are mean \pm S.E.M.; ${ }^{*} p<0.05,{ }^{* *} p<0.01$, significantly different from control; ANOVA followed Dunnett's test $(n=$ 6)

antinociceptive activity of the extract at dose of $100 \mathrm{mg} / \mathrm{kg}$ in the first phase of this test. The effect of morphine $(10 \mathrm{mg} / \mathrm{kg})$ was also reversed by naloxone.

\section{Opioid antinociceptive activity}

Figure 4 shows the results of the hot plate test. The reaction time parameter was only significantly increased at a dose of $100 \mathrm{mg} / \mathrm{kg}$ in $60 \mathrm{~min}$. The effect of morphine was reversed by naloxone.

\section{Acute toxicity}

In the acute toxicity of $\mathrm{BI}-\mathrm{EtOH}$, behavioral and physiological alterations were not observed. No animals died from the $2.0 \mathrm{~g} / \mathrm{kg}$ intraperitoneally and $5.0 \mathrm{~g} / \mathrm{kg}$ orally, respectively, indicating low toxicity of the extract. The administration of the extract did not cause any appreciable alterations in water and food intake in any of the groups. Moreover, body weight gain during the observation period among the treated animals with $5 \mathrm{~g} / \mathrm{kg}$ v.o. was statistically different when comparable to control group (Figure 5).

\section{Hematological and biochemical profiles}

The administration of intraperitoneal and oral doses of BI-EtOH did not cause erythrocytes, hemoglobin, hematocrit, $\mathrm{MCV}, \mathrm{MCH}, \mathrm{MCHC}$, leukocytes, lymphocytes and platelets level to change (Table 1).

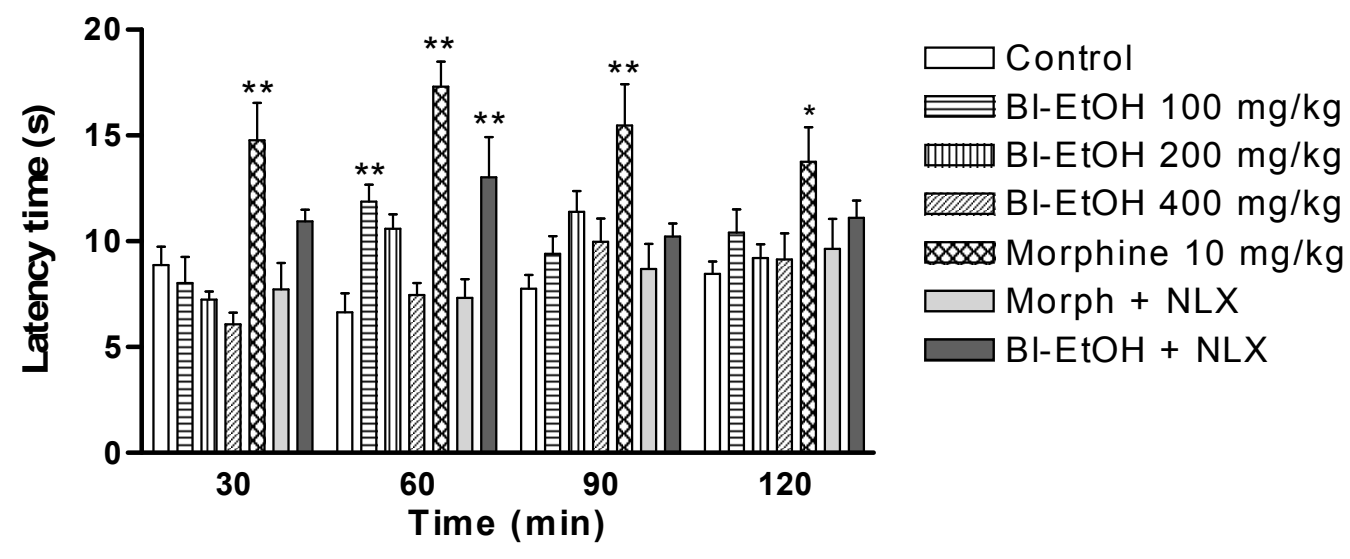

Figure 4: Effect of ethanolic extract of $B$. laciniosa $(B I-E t O H)$, morphine, morphine + naloxone (Morph + NLX; 10 $\mathrm{mg}+1.5 \mathrm{mg} / \mathrm{kg})$ and Bl-EtOH $+\mathrm{NLX}(100 \mathrm{mg}+1.5 \mathrm{mg} / \mathrm{kg})$ on hot plate test; values are mean \pm S.E.M.; ${ }^{*} p<$ $0.05,{ }^{* *} p<0.01$, significantly different from control; ANOVA followed Dunnett's test $(\mathrm{n}=6)$ 


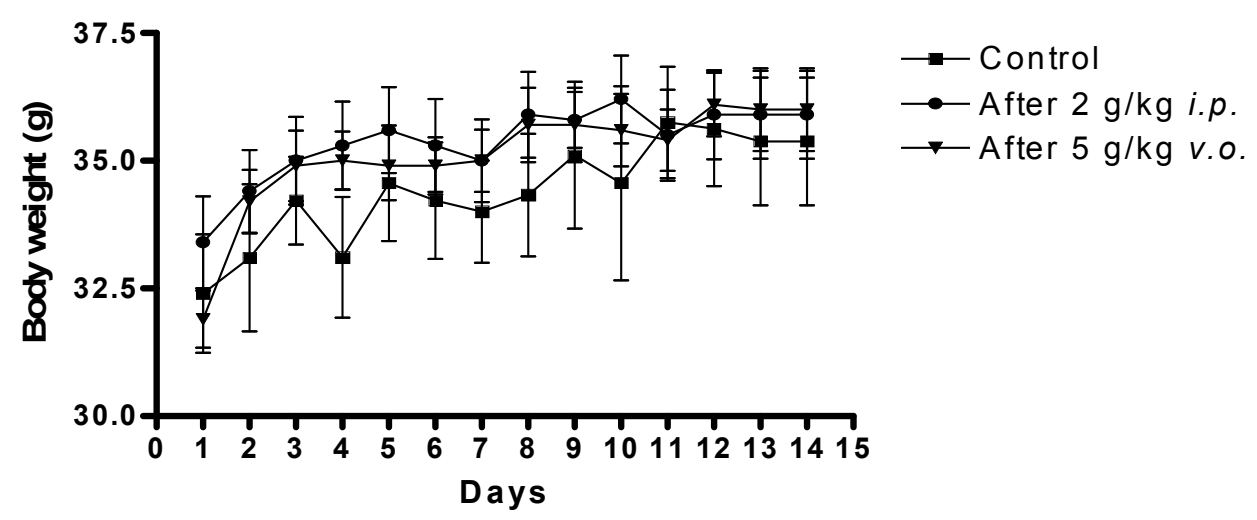

Figure 5: Body weight of animals treated with Bl-EtOH for 14 days $(n=10)$

Table 1: Hematological profiles of Swiss mice treated with $2.0 \mathrm{~g} / \mathrm{kg}$ intraperitoneally and $5.0 \mathrm{~g} / \mathrm{kg}$ orally of crude ethanol extract of Bromelia laciniosa after 14 days

\begin{tabular}{llll}
\hline Parameter & \multicolumn{3}{c}{ Group } \\
\cline { 2 - 4 } & Control & Extract, $\mathbf{2 g} / \mathbf{k g}$ i.p. & Extract, 5g/kg oral \\
\hline Erythrocytes $\left(10^{6} / \mathrm{mm}^{3}\right)$ & $8.05 \pm 0.49$ & $8.43 \pm 0.15$ & $8.09 \pm 0.09$ \\
Hemoglobin $(\mathrm{g} / \mathrm{dl})$ & $13.40 \pm 0.91$ & $12.88 \pm 0.68$ & $13.06 \pm 0.27$ \\
Hematocrit $(\%)$ & $42.41 \pm 2.48$ & $43.33 \pm 1.25$ & $42.84 \pm 0.40$ \\
MCV $\left(\mu^{3}\right)$ & $52.60 \pm 1.36$ & $51.88 \pm 0.45$ & $52.86 \pm 0.46$ \\
MCH $(\mu \mathrm{g})$ & $16.60 \pm 0.22$ & $16.43 \pm 0.18$ & $16.78 \pm 0.15$ \\
MCHC $(\%)$ & $31.69 \pm 0.83$ & $31.88 \pm 0.34$ & $32.06 \pm 0.40$ \\
Leukocytes $\left(10^{3} / \mathrm{mm}^{3}\right)$ & $6.25 \pm 0.57$ & $5.88 \pm 0.41$ & $6.97 \pm 0.59$ \\
Lymphocites $(\%)$ & $88.93 \pm 5.36$ & $88.53 \pm 1.08$ & $88.55 \pm 1.35$ \\
Platelets $\left(10^{3} / \mathrm{mm}^{3}\right)$ & $883.70 \pm 108.30$ & $856.90 \pm 71.14$ & $911.30 \pm 73.18$ \\
\hline
\end{tabular}

Values are mean \pm SEM $(n=10)$; Student's t-test $(p<0.05)$

Table 2: Serum biochemical profile of Swiss mice treated with $2.0 \mathrm{~g} / \mathrm{kg}$ intraperitoneally and $5.0 \mathrm{~g} / \mathrm{kg}$ orally of ethanol extract of Bromelia laciniosa for 14 days

\begin{tabular}{llll}
\hline Parameter & Group & & \\
\cline { 2 - 4 } & Control & Extract, 2 g/kg i.p. & Extract, 5 g/kg oral \\
\hline Triglycerides $(\mathrm{mg} / \mathrm{dl})$ & $133.30 \pm 5.57$ & $111.17 \pm 15.21$ & $141.80 \pm 14.14$ \\
AST/GOT $(\mathrm{U} / \mathrm{l})$ & $123.10 \pm 11.23$ & $111.70 \pm 25.05$ & $116.70 \pm 12.61$ \\
ALT/GPT $(\mathrm{U} / \mathrm{l})$ & $75.29 \pm 8.58$ & $60.23 \pm 8.08$ & $66.30 \pm 7.22$ \\
Urea $(\mathrm{mg} / \mathrm{dl})$ & $66.44 \pm 4.40$ & $65.89 \pm 6.16$ & $67.56 \pm 4.84$ \\
Creatinine $(\mathrm{mg} / \mathrm{dl})$ & $0.36 \pm 0.01$ & $0.42 \pm 0.11$ & $0.26 \pm 0.02^{* *}$ \\
\hline
\end{tabular}

Values are mean \pm SEM $(n=10) ;{ }^{* *} p<0.01$; Student's t-test $(p<0.05)$

Likewise, the values of triglycerides, AST/GOT, ALT/GPT and urea (mg/dl) showed no significant changes. However, a significant decrease in the creatinine in the group treated with $5 \mathrm{~g} / \mathrm{kg}$ by oral route was observed when compared to the control group (Table 2).

\section{DISCUSSION}

The present study shows that the ethanolic extract of Bromelia laciniosa has phenolic compounds, which are possibly responsible for their antinociceptive properties. A HPLC fingerprint of phenolic compounds was developed and showed the presence of characteristic peaks for these compounds.
The first test to evaluate the antinociceptive activity of $\mathrm{Bl}-\mathrm{EtOH}$ was the writhing induced by acetic acid. Acetic acid-induced writhing is a standard, simple, and sensitive test for measuring analgesia induced by both opioids and peripherally acting analgesics. Additionally, although this test is a nonspecific model, it is widely used for analgesic screening and involves local peritoneal receptors [21]. Bl-EtOH significantly reduced the acetic acid-induced writhing in mice. These results support the hypothesis of $\mathrm{Bl}-\mathrm{EtOH}$ participation in the inhibition of prostaglandin synthesis, as the nociceptive mechanism involves the process or release of arachidonic acid metabolites via cyclooxygenase (COX), prostaglandin biosynthesis or other peripheral pathway [22]. A 
positive result with this test is indicative of antinociceptive activity in the extract under investigation, which may be of central or peripheral origin.

In order to distinguish between the central and peripheral antinociceptive action, the formalin test was performed. Subcutaneous injection of formalin into the animal hind paw evokes an array of stereotyped behaviors. The nociceptive response to formalin occurs in a biphasic pattern; there is an initial acute period (phase 1) and, after a short period of remission, phase 2 begins and consists of a longer period of sustained activity. The phase 1 corresponds to acute nociceptive neurogenic pain, and is sensitive to analgesic drugs that interact with opioid system. The phase 2 corresponds to an inflammatory pain, dependent on several inflammatory mediators release and action, and the expression of nociceptive behavior in this phase is very sensitive to non-steroid anti-inflammatory drugs as the cyclooxygenase inhibitors. Drugs that act primarily as central analgesics inhibit both phases while peripherally acting drugs inhibit only the second phase [23]. The extract was able to block both phases of the formalin response although the effect was more pronounced in the second phase. The effect of extract on the first and second phases of formalin test suggests that its activity may be resulted from its central action when compared with morphine activity in this respect. The pre-treatment with naloxone reversed the antinociceptive activity of the extract in the first phase of this test. The results suggest a possible involvement of opioid receptors in the antinociceptive effect of the extract. In this study, acetylsalicylic acid and morphine was also able to inhibit both phases of the formalin test. Previous study showed that acetylsalycilic acid and paracetamol to have actions independent of their inhibition of prostaglandin synthesis and they also have effects on non-inflammatory pain [24], which was observed in this study for the AAS.

The evaluation of $\mathrm{Bl}-\mathrm{EtOH}$ on hot plate response showed that the extract increases the latency time only at dose of $100 \mathrm{mg} / \mathrm{kg}$ after $60 \mathrm{~min}$. As the hot plate test is a specific central antinociceptive test, it is possible that $\mathrm{Bl}-\mathrm{EtOH}$ exert their antinociceptive effect at least in part through central mechanisms, as observed in the formalin test by inhibition of both phases of the test.

The use of medicinal plants has been very significant in several populations, especially in the Northeast of Brazil. However, the popular or traditional uses are not sufficient to validate the herbal medicines as effective and safe. It is necessary to carry out toxicological studies to evaluate safety parameters which are not observed in the popular use of these plants [25].

The tests for acute toxicity of Bl-EtOH did not demonstrate signs of lethality in mice at doses tested. A 2.0 and $5.0 \mathrm{~g} / \mathrm{kg}$ body weight administered by via intraperitoneal and oral, respectively, dose were considered as the "limit test", as recommended by acute toxicity testing procedures [20]. In the acute toxicity of Bl-EtOH, behavioral and physiological alterations were not observed and no animal died in the doses of 2.0 $\mathrm{g} / \mathrm{kg}$ intraperitoneally and $5.0 \mathrm{~g} / \mathrm{kg}$ orally, respectively, indicating low toxicity of the extract. In this experiment was observed that the BI$\mathrm{EtOH}$ has $\mathrm{LD}_{50}>5000 \mathrm{mg} / \mathrm{kg}$. According to Kennedy et al [26] substances that present LD $D_{50}$ higher than $5.0 \mathrm{~g} / \mathrm{kg}$ by oral route can be considered practically non-toxic.

There was no significant variation in hematological parameters in the groups treated with the extract compared to control. In regard to biochemical parameters a significant decrease in the creatinine in the group treated with $5 \mathrm{~g} / \mathrm{kg}$ by oral rout was observed when compared to the control group. Creatinine is a good indicator of kidney function. Alterations in their levels suggest alterations in this organ. Histopathological analysis of the kidneys revealed that the histological structure of renal tubules were preserved (data not shown).

\section{CONCLUSION}

The present work indicates that Bromelia laciniosa is a source of phenolic compounds and exhibit antinociceptive properties. Peripheral and, at least in part, central mechanisms may be involved in the antinociceptive effect. Further studies currently in progress will throw more light on the mechanisms of action underlying the effects observed in this investigation. The results obtained so far show that the plant is non-toxic at the doses used.

\section{ACKNOWLEDGEMENT}

This work was supported by grants from Brazilian agencies CNPq (Process 476770/2010-6) and FACEPE (Process APQ-0542-4.03/10).

\section{REFERENCES}

1. Chedier LM, Kaplan MAC. Chemical ecology of three species of Bromeliaceae. Bromelia 1996; 3: 25-31. 
2. Luther HE. An alphabetical list of bromeliad binomials. Sarasota, The Bromeliad Society International, 2008.

3. Manetti LM, Delaporte RH, Laverde-Junior A. Metabólitos secundários da família Bromeliaceae. Quim. Nova 2009; 7: 1885-1897.

4. Delaporte RH, Sarragiotto MH, Takemura OS, Sanchez $G M$, Filho BPD, Nakamura CV. Evaluation of the antioedematogenic, free radical scavenging and antimicrobial activities of aerial parts of Tillandsia streptocarpa Baker - Bromeliaceae. J. Ethnopharmacol. 2004; 95: 229-233.

5. Amendoeira FC, Frutuoso VS, Chedier LM, Pearman AT, Figueiredo MR, Kaplan MAC, Prescott SM, Bozza PT, Castro-Faria-Neto HC. Antinociceptive effect of Nidularium procerum: a Bromeliaceae from the Brazilian coastal rain Forest. Phytomedicine 2005; 12: 78-87.

6. Vieira-de-Abreu A, Amendoeira FC, Gomes GS, Zanon $C$, Chedier LM, Figueiredo MR, Kaplan MA, Frutuoso VS, Castro-Faria-Neto HC, Weller PF, et al. Antiallergic properties of the Bromeliaceae Nidularium procerum: Inhibition of eosinophil activation and influx. Int Immunopharmacol. 2005; 5: 1966-1974.

7. Carvalho KIM, Fernandes HB, Machado FDF, Oliveira IS, Oliveira FA, Nunes PHM, Lima JT, Almeida JRGS, Oliveira RCM. Antiulcer activity of ethanolic extract of Encholirium spectabile Mart. ex Schult \& Schult $f$. (Bromeliaceae) in rodents. Biol Res. 2010; 43: 459465.

8. Manetti LM, Turra AF, Takemura OS, Svidzinski TIE, Laverde-Junior A. Avaliação das atividades antimicrobiana, citotóxica, moluscicida e antioxidante de Bromelia antiacantha Bertol. (Bromeliaceae). Rev. Bras. PI. Med. 2010; 12: 406-413.

9. Coelho RG, Honda NK, Vieira MC, Brum RL, Pavan FR, Leite CQF, Cardoso CAL. Chemical composition and antioxidant and antimycobacterial activities of Bromelia balansae (Bromeliaceae). J Med Food 2010; 13: 1277-1280.

10. Agra MF, Freitas PF, Barbosa-Filho JM. Synopsis of the plants known as medicinal and poisonous in Northeast of Brazil. Braz. J. Pharmacogn. 2007; 17: 114-140.

11. Santos VNC, Freitas RA, Deschamps FC, Biavatti, MW. Ripe fruits of Bromelia antiacantha: investigations on the chemical and bioactivity profile. Braz. J. Pharmacogn. 2009; 19: 358-365.

12. Dutra AS, Teófilo EM, Medeiros-Filho S. Germinação de sementes de macambira (Bromelia laciniosa Mart. ex Schult). Revista Caatinga 2010; 23: 12-17.

13. Angelim AES, Moraes JPS, Silva JAB, Gervásio, RCRG. Germinação e aspectos morfológicos de plantas de macambira (Bromelia laciniosa), encontradas na Região do Vale do São Francisco. R. Bras. Bioci. 2007; 5: 1065-1067.

14. Albuquerque UP, Medeiros PM, Almeida ALS, Monteiro $J M$, Lins-Neto EMF, Melo JG, Santos JP. Medicinal plants of the caatinga (semi-arid) vegetation of NE Brazil: a quantitative approach. J Ethnopharmacol. 2007; 114: 325-354.

15. Koster R, Anderson M, De Beer EJ. Acetic acid for analgesic screening. Fed Proc. 1959; 18: 412-416.

16. Queiroz $A C$, Lira $D P$, Dias $T L$, Souza $E T$, Matta $C B$, Aquino $A B$, Silva $L H$, Silva $D J$, Mella $E A$, Agra $M F$, Barbosa-Filho JM, Araújo-Júnior JX, Santos BV, Alexandre-Moreira MS. The antinociceptive and antiinflammatory activities of Piptadenia stipulacea Benth. (Fabaceae). J. Ethnopharmacol. 2010; 128: 377-383.

17. Oliveira RRB, Góis RMO, Siqueira RS, Almeida JRGS, Lima JT, Nunes XP, Oliveira VR, Siqueira JS, Quintans-Júnior LJ. Antinociceptive effect of the ethanolic extract of Amburana cearensis (Allemão) A.C. Sm., Fabaceae, in mice. Braz J Pharmacogn. 2009; 19: 672-676.

18. Almeida JRGS, Lima JT, Oliveira HR, Oliveira MR, Meira PRM, Lúcio ASSC, Barbosa-Filho JM, QuintansJúnior LJ. Antinociceptive activity of discretamine isolated from Duguetia moricandiana. Nat Prod Res. 2011; 25: 1908-1915.

19. Litchfied JT, Wilcoxon F. A simplified method of evaluating dose-effect experiments. J. Pharmacol. Exp. Ther. 1949; 96: 99-113.

20. Vasconcelos THC, Modesto-Filho J, Diniz MFFM, Santos $H B$, Aguiar FB, Moreira PVL. Estudo toxicológico préclínico agudo com o extrato hidroalcoólico das folhas de Cissus sicyoides L (Vitaceae). Braz J Pharmacogn 2007; 17: 583-591.

21. Alexandre-Moreira MS, Piuvezam MR, Araújo CC, Thomas G. Studies on the anti-inflammatory and analgesic activity of Curatella americana $L \mathrm{~J}$ Ethnopharmacol. 1999; 67: 171-177.

22. Guimarães AG, Melo MS, Bonfim RR, Passos LO, Machado SMF, Ribeiro AS, Sobral M, Thomazzi SM, Quintans-Júnior LJ. Antinociceptive and antiinflammatory effects of the essential oil of Eugenia candolleana DC., Myrtaceae on mice. Braz. J. Pharmacogn. 2009; 19: 883-887.

23. Couto VM, Vilela FC, Dias DF, Santos MH, Soncini $R$, Nascimento CGO, Giusti-Paiva A. Antinociceptive effect of extract of Emilia sonchifolia in mice. $J$ Ethnopharmacol. 2011; 134: 348-353.

24. Hunskaar $S$, Hole $K$. The formalin test in mice: dissociation between inflammatory and noninflammatory pain. Pain 1987; 30: 103-114.

25. Almeida JRGS, Guimarães AL, Oliveira AP, Araújo ECC, Silva FS, Neves LF, Oliveira RA, Sá PG, QuintansJúnior LJ: Evaluation of hypoglycemic potential and pre-clinical toxicology of Morus nigra L. (Moraceae). Lat. Am. J. Pharm. 2011; 30: 96-100.

26. Kennedy GL, Ferenz RL, Burgess BA. Estimation of acute oral toxicity in rats by determination of the approximate lethal dose rather than the LD50. J. Appl. Toxicol. 1986; 6: 145-148. 